\title{
Performance Evaluation of a Minor Irrigation Project Using Canal Performance Indicator
}

\author{
Mahesh P. Tripathi*, R.K. Nema, M.K. Awasthi and Y.K. Tiwari \\ Department of Soil and Water Engineering, J.N. K. V. V., Jabalpur, India \\ *Corresponding author
}

\section{A B S T R A C T}

Keywords

Performance

indicators, Minor

irrigation project,

Efficient planing,

Finical indicator

Article Info

Accepted:

14 December 2017

Available Online:

10 January 2018
Any Irrigation system always intended to increase crop production and increased farm incomes to the rural households as it provides cyclical development in different sectors of the economy as a whole. The study was conducted to evaluate the performance of Khapa a minor irrigation project located in Mandla district of Madhya Pradesh (India). The study considered various canal and finical indicator to check the current status economic utilization visibility of existing minor irrigation project. The results indicated that the resource utilization in current prospective were not fully utilized and efficient planing need to be done increase the productivity as well as farm income.

\section{Introduction}

Shortage of water and improper irrigation scheduling are the main limiting factors for agricultural production. Despite annual expansion in the created potential and capital investment in irrigation sector the area irrigated by the major, medium and minor irrigation systems has been either stagnating or declining from mid-80 or mid- 90 s due to improper distribution of infrastructure (Selvarajan, 2001) and improper utilizaion of water resources India has made tremendous progress in development of its irrigation potential. However, only about two-third of the created irrigation potential is actually being utilized and overall project irrigation efficiencies are very poor. Applying water to crop through irrigation increases yield and production in agriculture. However, inappropriate management of irrigation schemes might lead to environmental problems such as a high water table and poor drainage and thus salinization and pollution in addition to low quality of water. Assessing the performance of irrigated agriculture is necessary in order to evaluate the impact of agricultural and hydrological interventions. The performance of many agriculture systems is significantly below their potential due to number of shortcomings, such as poor design, construction, operation and maintenance. 
In the state of Madhya Pradesh hardly 49 per cent of total cultivable area can be brought under irrigation by utilizing all available water resources considering wells and tube wells are the major sources of irrigation covering almost $66 \%$ of net irrigated area. Canals constitute $18 \%$ and tanks constitutes 2\%share of irrigated area. At present, there are 12 major, 89 medium and 4506 minor completed schemes in the state. Apart from aforesaid completed schemes, 8 major, 35 medium and 676 minor schemes are in various stages of construction. The Irrigation potential through irrigation projects in M.P. is 31.89 lakh-ha and actual irrigation achieved in 23.80 (Status Note on PIM 2014, NPIM, M.P, 2014).

In past, there were several studies had been conducted on performance indicators revealed that evaluation of actual irrigation system performance should rely on an accurate hydrologic water balance over the area considered.

There are many equations, procedures and examples were derived for making these calculations and recommended that confidence intervals be included in all reporting of irrigation performance parameters. (Navaneeth, 2007 et al., Nelson, 2002 et al.,). The present study was undertaken to evaluate the performance of Khapa minor irrigation project using canal and financial performance indicators suggested by IWMI for the years 2016-2017.

\section{Materials and Methods}

\section{Details of Study area}

The area selected for study is the command area of Khapa, Dhudhwa and Magardha villages (shown in Fig.1), located in at Mandla district of Madhya Pradesh. The study area lying is $23^{\circ} 0$ ' 59.04' $\mathrm{N}$ latitude and $80^{\circ}$ 9' 22.02" E longitude. The Khapa tank is a major irrigation source for Khapa and Magardha village, which is earthen type tank with concrete waste weir, having catchment area of $7.73 \mathrm{~km}^{2}$.

The command area has maximum Rainfall (Annual) $208.07 \mathrm{~cm}$, Minimum rainfall (Annual) $89.94 \mathrm{~cm}$, Average rainfall (Annual) (for forty years) 148.33, Dependable rainfall at 75\% dependability (Annual) 120.39 and Yield on $75 \%$ dependability $3438.48 \mathrm{mcm}$. The climate of the locality is characterized as typically semi-humid and tropical which is featured by hot dry summer and cool dry winter. In order to study existing cropping pattern in command area the land revenue record of last ten years was studied. The existing cropping pattern found in the command area includes Wheat, Gram, Pea, Masoor and Mustard in Rabi season; Paddy, Maize, Kondo and Arahar in Kharif season. In command area of Khapa tank, it was observed that the actual area under crops was very less in Rabi session, hence grouping of crops were done into Gram, Pea, Masoor and Mustard.

\section{Materials and Methods}

In this study, Performance of the Scheme was evaluated using some selected comparative indicators, classified into two groups, namely, agricultural and water-use performance by International Water Management Institute (IWMI) (Molden et al., 1998). These performance indicators were evaluated through field visits, analyzing survey and collecting information from water resources department (M.P.,). The rainfall and crop data were collected from Sub-Division Office, Irrigation Department, Government of Madhya Pradesh, Mandla. The main output considered for the study is crop yield and foremost inputs are water and land. Cropped area, command area, evapotranspiration, peak demand, water diverted by canal, rainfall and production value. 
The evapotranspiration was computed using Penman-Monteith equation. For calculation of production, the yield obtained is collected through field survey using questionnaire. The major performance indicator evaluated in the study is given as following:

$\underset{\text { SGVP }}{\text { Output per cropped area (Rs/ha) = }}$

Irrigated cropped area

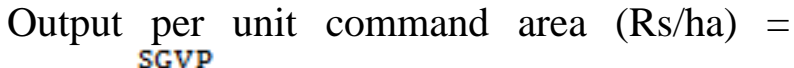
Command cropped area

Output per unit water consumed $\left(\mathrm{Rs} / \mathrm{m}^{3}\right)=$ SGVP

Volume of water consumed by ET

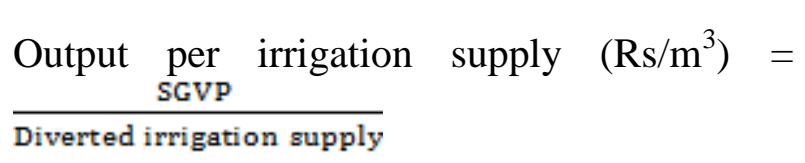

Evaluation of the irrigation projects.

Relative water supply $=\frac{\text { Total water supply }}{\text { Crop demand }}$

Relative irrigation supply $=\frac{\text { Irrigation demand }}{\text { Irrigation supply }}$

Water delivers capacity $(\%)=$ canal capasity to deliver water at system head peak cosumptive demand

\section{Results and Discussion}

\section{Estimated of Crop Water Requirements (CWR) and Irrigation Requirements (IR)}

The seasonal crop water requirements and irrigation water requirements of the Rabi crops grown in which command area between period 2015-16 and 2016-17. As estimated by the CROPWAT model. The results indicate that for two years, the seasonal crop water requirements and irrigation water requirements were not equal because there was difference in rainfall during the period occurs.

Rabi crop in period 2015-16 and 2016-17, which was planted at the beginning of mid Oct-November and harvested during the March-April was estimated as 7.16, 7.89 $\mathrm{mm} / \mathrm{season}$ and 4.49, $5.25 \mathrm{~mm} / \mathrm{season}$ respectively.

\section{Comparative performance indicators}

The type and capacity of the irrigation systems of Khapa irrigation project between period 2015-16 and 2016-17 for the study are shown in Table 3.3.

\section{Estimated to equation of standardized (Standardized Gross Value Production)}

Estimated of the standardized Gross Value Production (SGVP) of rabi crops grown in which Khapa and Magardha command area between period 2015-16 and 2016-17 as given in below.

Comparison of the irrigation projects (Agriculture performance)

The major of such performance indicators included are output per unit cropped area, output per unit of command area, output per unit irrigation supply and output per unit water consumed as given the below.

\section{Output per unit-cropped area}

This indicator specifies Output per unit cropped area. Figure 2 shows that the output per unit-cropped area of Khapa irrigation project obtained between the periods 2015-16 and 2016-17. The result shows that the production rate obtained varied between 23264 to $32895 \mathrm{Rs} / \mathrm{ha}$. during the rabi season. The output per ha has been found increasing. 
Table.1 Crop Water Requirement (CWR) and Irrigation Requirement (IR) of year 2015 -16

\begin{tabular}{|l|c|c|c|c|c|}
\hline \multicolumn{1}{|c|}{ Crop } & $\begin{array}{c}\text { Area } \\
\text { (ha.) }\end{array}$ & $\begin{array}{c}\text { CWR } \\
\text { (mm/season) }\end{array}$ & IR(mm/season) & $\begin{array}{c}\text { Total } \\
\text { CWR }\end{array}$ & Total IR \\
\hline Wheat & 278 & 479.3 & 298 & 7.04 & 4.37 \\
\hline Mustard & 5.12 & 208.6 & 199.1 & 0.06 & 0.05 \\
\hline Gram & 3.7 & 165 & 166.1 & 0.03 & 0.03 \\
\hline Pea & 3.6 & 159 & 148.9 & 0.03 & 0.03 \\
\hline Total & $\mathbf{2 9 0 . 4 2}$ & & & $\mathbf{7 . 1 6}$ & $\mathbf{4 . 4 9}$ \\
\hline
\end{tabular}

Table.2 Crop Water Requirement (CWR) and Irrigation Requirement (IR) of year 2016-17

\begin{tabular}{|l|c|c|c|c|c|}
\hline \multicolumn{1}{|c|}{ Crop } & $\begin{array}{c}\text { Area } \\
\text { (ha.) }\end{array}$ & CWR(mm/season) & IR(mm/season) & $\begin{array}{c}\text { Total } \\
\text { CWR }\end{array}$ & Total IR \\
\hline Wheat & 282 & 436.5 & 213.3 & 7.73 & 5.14 \\
\hline Mustard & 5.15 & 222.9 & 221.8 & 0.07 & 0.05 \\
\hline Gram & 3.9 & 198.2 & 192.1 & 0.05 & 0.03 \\
\hline Pea & 3.8 & 159.9 & 159.9 & 0.04 & 0.03 \\
\hline Total & $\mathbf{2 9 4 . 8 5}$ & & & $\mathbf{7 . 8 9}$ & $\mathbf{5 . 2 5}$ \\
\hline
\end{tabular}

Table.3 Features and computed values of some parameters of Khapa Irrigation Projects

\begin{tabular}{|c|c|c|c|c|c|}
\hline Years & $\begin{array}{l}\text { Diverted } \\
\text { irrigation supply } \\
\left(\mathrm{m}^{3}\right)\end{array}$ & $\begin{array}{l}\text { Irrigation supply } \\
\left(\mathrm{m}^{\mathbf{3}}\right)\end{array}$ & $\begin{array}{l}\text { Volume } \\
\text { ET }\left(\mathrm{m}^{\mathbf{3}}\right)\end{array}$ & $\begin{array}{l}\text { Total } \\
\text { water } \\
\text { supply } \\
\left(\mathbf{m}^{\mathbf{3}}\right)\end{array}$ & $\begin{array}{l}\text { Capacity of } \\
\text { canal head } \\
\text { (Cumec) }\end{array}$ \\
\hline $\begin{array}{c}\mathbf{2 0 1 5}- \\
\mathbf{1 6}\end{array}$ & 1727300 & 1727300 & 684880.00 & 1875700 & 0.481 \\
\hline $\mathbf{2 0 1 6 -}$ & 1747300 & 1747300 & 937650.00 & 1802008 & 0.481 \\
\hline $\mathbf{1 7}$ & & & & & \\
\hline
\end{tabular}

Table.4 Standardized SGVP (2015-16)

\begin{tabular}{|c|l|l|l|l|l|l|l|c|}
\hline SL.NO & Crop & $\begin{array}{c}\text { Ai } \\
\text { Crop } \\
\text { area } \\
\text { (ha.) }\end{array}$ & $\begin{array}{c}\text { Yield } \\
\text { (ton/h } \\
\text { a.) }\end{array}$ & $\begin{array}{c}\text { Producti } \\
\text { on } \\
\text { (ton) }\end{array}$ & $\begin{array}{c}\text { Prices } \\
\text { (Rs./ton) }\end{array}$ & $\begin{array}{c}\text { prices } \\
\text { (Rs./to } \\
\text { n) }\end{array}$ & $\begin{array}{c}\text { Prices } \\
\text { (Rs./to } \\
\text { n) }\end{array}$ & (Rs.) \\
\hline $\mathbf{1}$ & Whea & 278 & 1.80 & 500.40 & 15250 & 35000 & 29526 & 6089617.8 \\
\hline $\mathbf{2}$ & Must & 5.12 & 0.80 & 4.10 & 37000 & 37000 & 28526 & 317880 \\
\hline $\mathbf{3}$ & Gram & 3.7 & 0.50 & 1.85 & 14500 & 13600 & 8613 & 78897 \\
\hline $\mathbf{4}$ & Pea & 3.6 & 0.40 & 1.44 & 6500 & 13600 & 8513 & 27529 \\
\hline Total & & $\mathbf{2 9 0 . 4 2}$ & $\mathbf{0 . 8 8}$ & $\mathbf{5 0 7 . 7 9}$ & & & & $\mathbf{6 5 1 3 9 2 4 . 5 9}$ \\
\hline
\end{tabular}


Table.5 Standardized SGVP (2016-17)

\begin{tabular}{|c|l|l|l|l|l|l|l|l|}
\hline SL.NO & Crop & $\begin{array}{c}\text { Crop } \\
\text { area } \\
\text { (ha.) }\end{array}$ & $\begin{array}{c}\text { Yield } \\
\text { (ton/h } \\
\text { a.) }\end{array}$ & $\begin{array}{c}\text { Producti } \\
\text { on } \\
\text { (ton) }\end{array}$ & $\begin{array}{c}\text { Prices } \\
\text { (Rs./ton }\end{array}$ & $\begin{array}{c}\text { Prices } \\
\text { (Rs./to } \\
\text { n) }\end{array}$ & $\begin{array}{l}\text { Prices( } \\
\text { Rs./ton }\end{array}$ & (Rs.) \\
\hline 1 & Whea & 282 & 2.50 & 705 & 15567 & 35000 & 29526 & 8757839 \\
\hline 2 & Must & 5.15 & 0.90 & 4.64 & 37000 & 37000 & 28434 & 358551 \\
\hline 3 & Gram & 3.9 & 0.70 & 2.73 & 14500 & 13600 & 887.12 & 116426 \\
\hline 4 & Pea & 3.8 & 0.60 & 2.28 & 6500 & 13600 & 8613.13 & 43588 \\
\hline Total & & $\mathbf{2 9 4 . 8 5}$ & $\mathbf{1 . 1 8}$ & $\mathbf{7 1 4 . 6 5}$ & & & & $\mathbf{9 2 7 6 4 0 3}$ \\
\hline
\end{tabular}

Fig.1 Location map of Kapa minor irrigation project

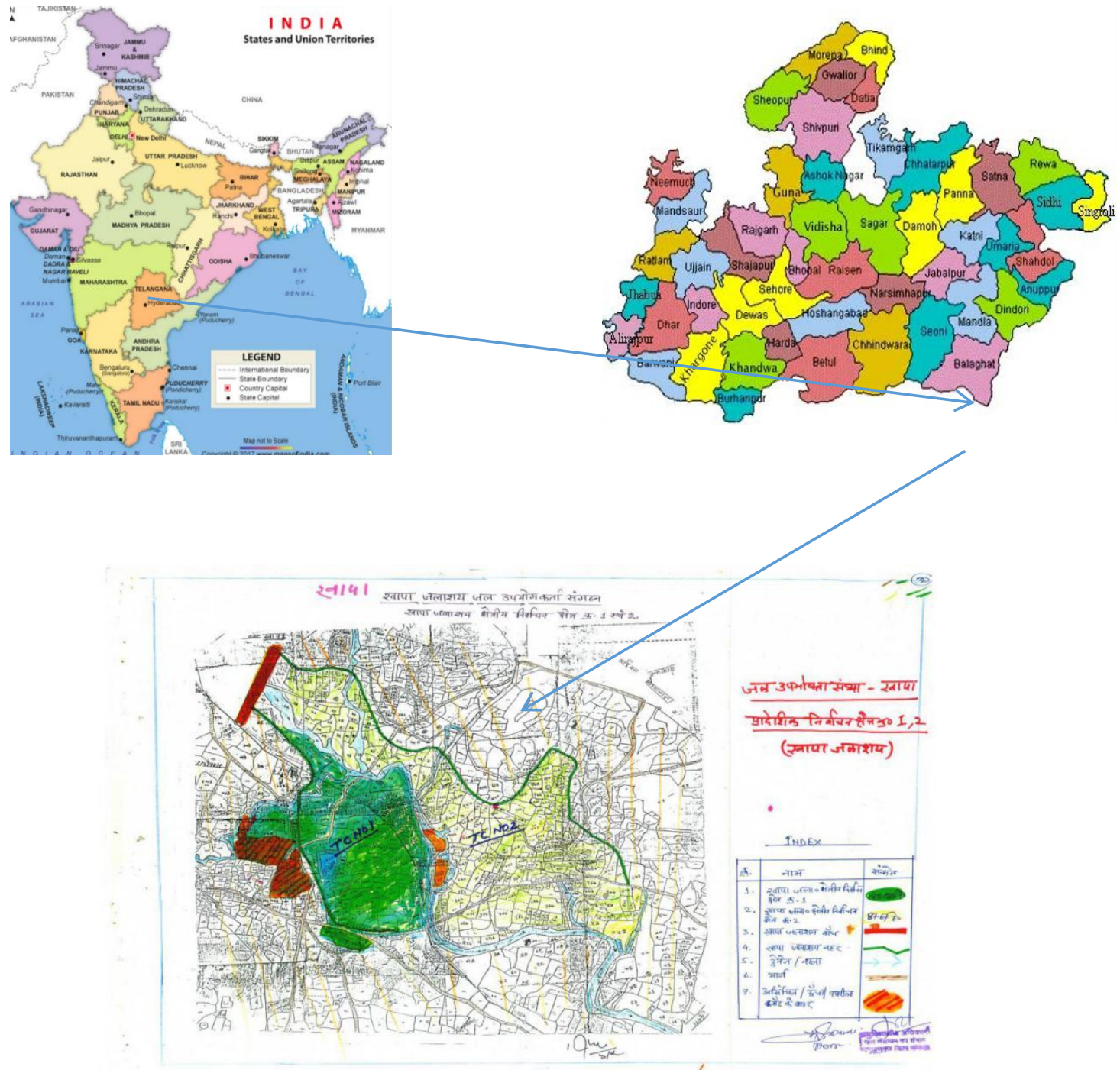

Index map of Kapa Minor Irrigation Project 
Fig.2 Outputs per unit cropped area

Fig.3 Outputs per unit command

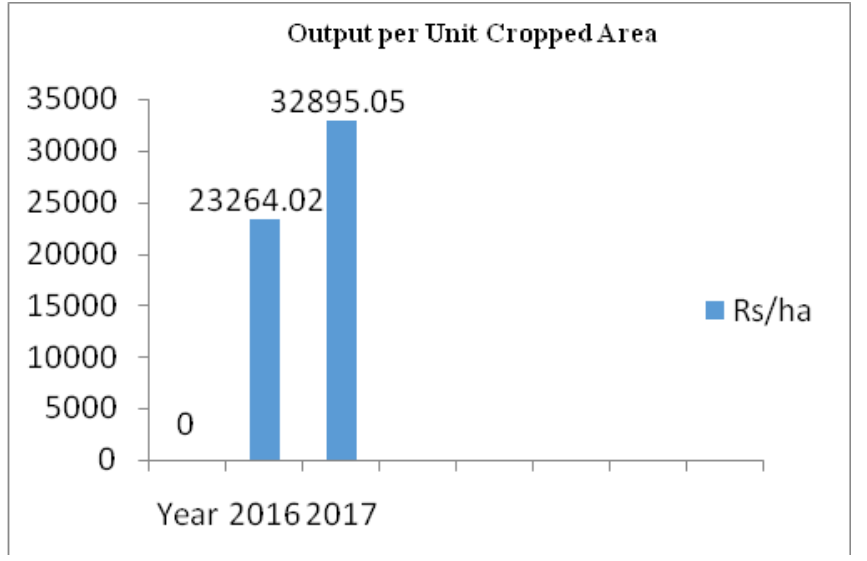

Fig.4 Output per unit water consumed

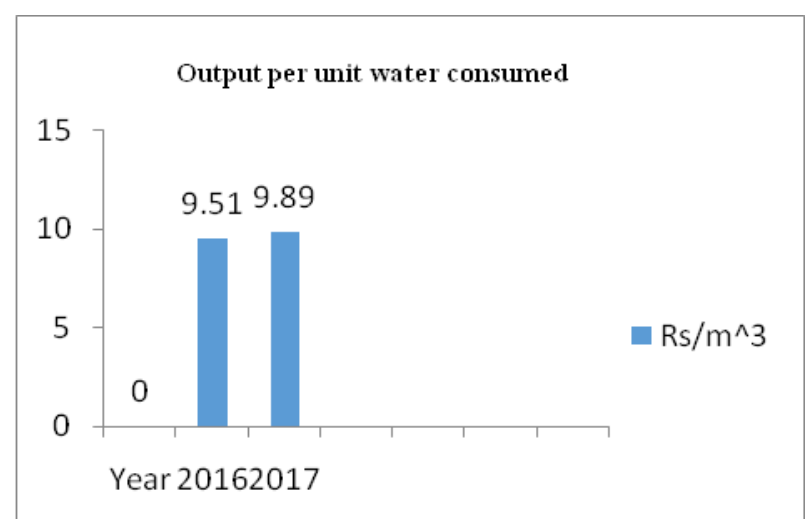

Fig.6 Relative water supply

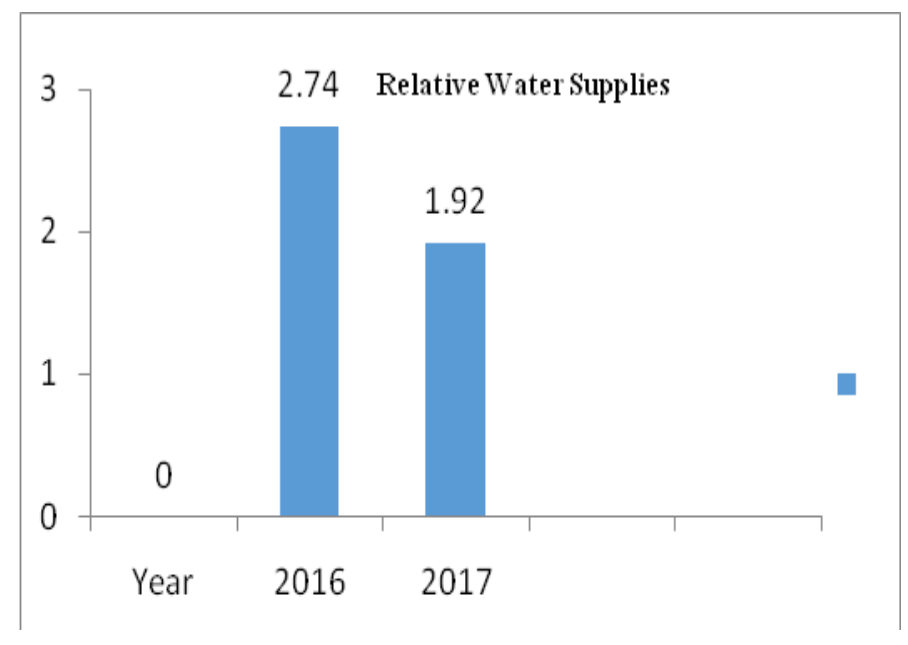

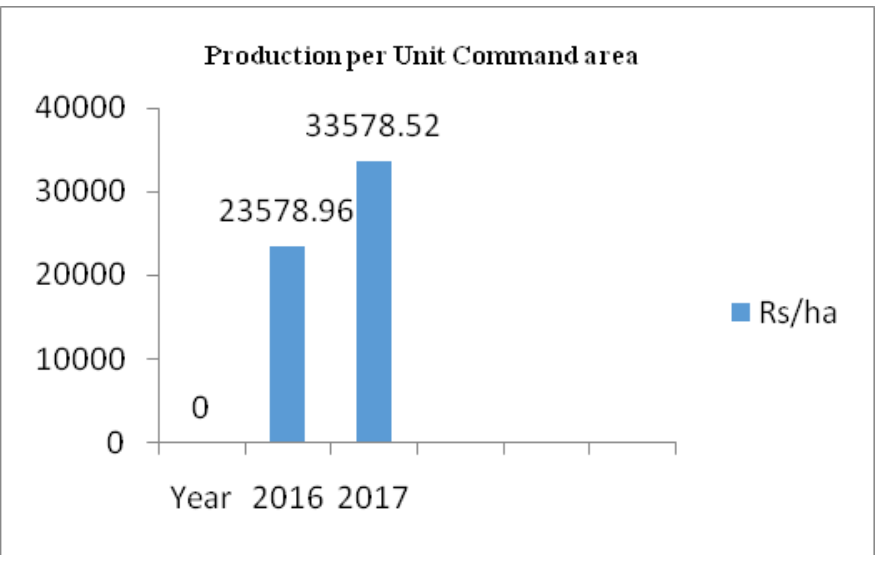

Fig.5 Outputs per unit irrigation supply

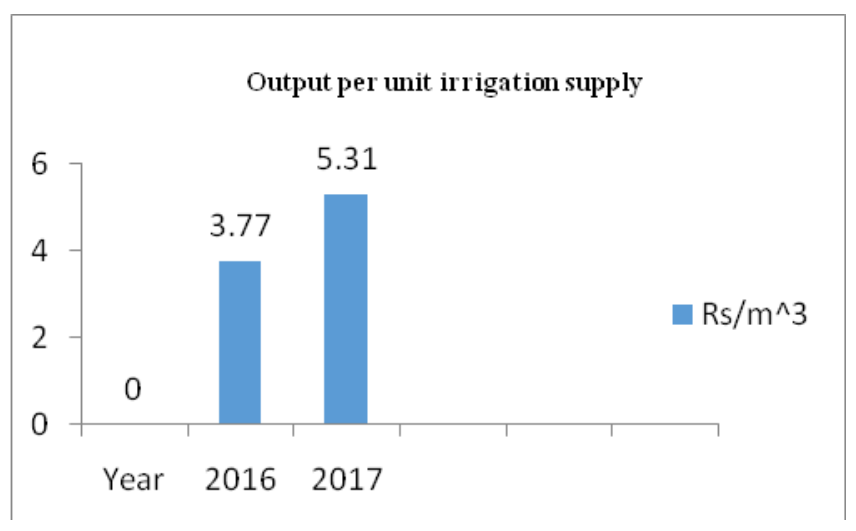

Fig.7 Relative irrigation supply

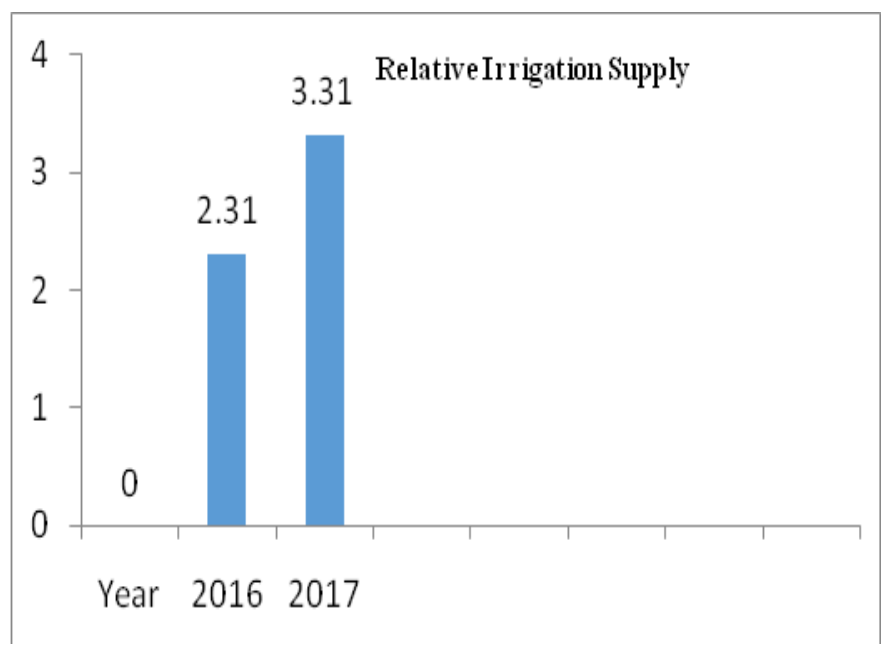


Fig.8 Water delivery capacities

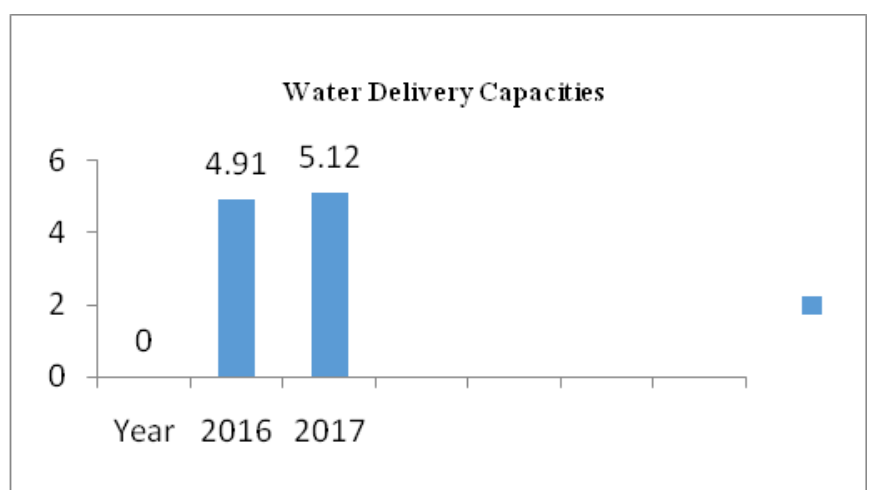

It was $23264 \mathrm{Rs} / \mathrm{ha}$. in year $2015-16$ and it increased upto $32895 \mathrm{Rs} / \mathrm{ha}$. in year 2016-17. The value of output per cropped unit area in year 2016-17 higher because the value of base crop was more than 2016-17 as compared to the 2015-16.

\section{Output per unit command area}

This indicator specifies Output per unit command area. Fig. 3, the result shows that the production rate obtained varied between 23578 to $33578 \mathrm{Rs} / \mathrm{ha}$ during the rabi season. The output per ha has been found increasing. The output per unit command area is compared for the last two years (i.e. 2016 and 2017). The output per-unit command area increases $23578 \mathrm{Rs} / \mathrm{ha}$ in year 2016 to 33578 $\mathrm{Rs} / \mathrm{ha}$ in year 2017. This indicator that there is a need to develop command area and increase cropped area in Khapa irrigation project. Because the present time excess irrigation supply is supplied at the Khapa and Magardha command.

This indicator specifies, Output per unit water consumed. It is determined by considering reference crop ET for rabi crops. The daily ETo values were estimated using FAO Penman Monteith method. The ETc values obtained on the basis of 15 years average data. This indicator shows the output obtained out of a unit of water volume consumed or evapotranspired by the crops. When we compare the four seasons result obtained it varied from 9.51 to $9.89 \mathrm{Rs} / \mathrm{m}^{3}$ show in the fig. 4, because the value of SGVP increased yearly. So output per unit water consumed per $\mathrm{m}^{3}$ is increased. The value of water consumed per $\mathrm{m}^{3}$ in the year 2016-17 was higher as compared to 2015-16 due to less water consumed and high gross returns.

\section{Output per unit irrigation supply}

This indicator specifies Output per unit irrigation supply. This indicator shows the value of output, per unit of irrigation supply varied between 3.77 and $5.31 \mathrm{Rs} / \mathrm{m}^{3}$. As shown in the fig.5.

There is large variation between the seasons. It was higher value for year 2016-17 due to less water consumed and high gross returns. To increase the value of Standardized Gross Value Production (SGVP) per unit irrigation supply, much more area cultivated with orchards, industrial crops and vegetable is needed.

\section{Evaluation of the irrigation projects (water use performance)}

Three types of indicators, relative water supply (RWS), relative irrigation supply (RIS) and water deliver capacity (WDC) were used for evaluation of water use performance (Levine, 1982 and Perry, 1996). 


\section{Relative Water Supply (RWS)}

Relative water supply ratio relates water supply to demand and indicates the condition of water abundance or scarcity and how tightly supply and demand is matched.

This indicator shows weather demand supply situation is met. The value of this indicator during Rabi-season in years 20015-16 and 2016-17 of the RWS was found as 2.74 and 1.92 respectively. The value more than 1.0 indicates that total water supply is enough to meet the crop demand. In year 2015-16 and 2016-17 get sufficient water supply to meet crop demand. The relative water supply was better in year 2016-17 as compared to year 2015-16 as shown in fig.6.

\section{Relative Irrigation Supply (RIS)}

Relative irrigation supply ratio relates irrigation supply to demand. The RIS is an indicator that shows the irrigation efficiency of the Khapa irrigation project. Because it compares the irrigation water supplied with the irrigation water needed. The value of this indicator during Rabi-season in years 2015-16 and 2016-17 of the RIS was found as 2.31 and 3.31 respectively. The value more than 1.0 indicates that irrigation supply by the canal is enough to meet the crop demand. Relative irrigation supply is better in year 2015-16 as compared to year 2016-17 as shown in fig.7.

\section{Water delivery capacity (WDC)}

The water delivery capacity ratio gives an indication of the degree to which irrigation infrastructure is in anyway constraining cropping intensities by comparing the canal conveyance capacity to peak consumptive demands.

The result shows that the dam's infrastructure is capable of delivering the necessary peak water demand. In four years of the Rabi season, the WDC ratio is greater than one (fig.8). This indicates that water delivery capacity in year 2015-16 was better than 2016-17. Higher value of this indicator in the year 2016-17 indicates that its capacity has lesser constraint to meet crop water demands. Since water delivery capacity values in 2015 16 and 2016-17 were greater than unity because there may not be difficulties in meeting short-term peak demands. But the water delivers capacity value in year 2015-16 was less than of unity because there may be difficulties in meeting sort-term peak demand.

The existing performance of Khapa irrigation project was determined using some agricultural, water use and financial indicators. The results showed that the output values were lower than recommended package of practices. To increase output, crop pattern should include orchards, industrial crops and vegetables. The performance indicators showed land and water was not the limitation in the command area. The existing prospective of command area was not fully utilized. This can be overcome by organizing the awareness among the farmers regarding the utilization of available land and water sources by adopting there commended package of practice.

\section{Acknowledgments}

I would like to extend sincere thanks to my adviser, Dr. R.K. Nema, for the knowledge, guidance and freedom he provided throughout the course of this project.

\section{References}

Levine G. 1982. Relative water supply: An explanatory variable for irrigation systems. Technical Report No. 6; the Determinants of Irrigation Project Problems in Developing Countries. 
Ithaca, NY: Cornell University.

Molden, Devid, Sakthivadivel, R. Charistipher Perry, J., Charlotte de fraiture and Kolzen. Wim H. 1998. Indicator for comparing performance of Irrigated Agricultural system. International Water Management Institute. Research Report 20. Colombo, Sri-Lanka.

NABARD. 2014. State Focus Paper, National Agriculture and Rural Development Bank (NABARD), Madhya Pradesh: pp 2-3.

Navaneeth B.S, 2007. "Performance of Minor Irrigation in Krishna Basin of Karnataka an Economic Perspective" University of Agriculture Dharwad, M.Sc Thesis, pp123-157.
Nelson, D.E. 2002. Performance Indicators for Irrigation Canal System Managers of Water Users Association. Updated version of a presentation at the international congress on Irrigation and Drainage, Montrel Canada.

Perry, J.L. 1996. Measuring Public Service Motivation: An Assessment of Construct Reliability and Validity. Journal of Public Administration Research and Theory 6 (1): 5-22.

Selvarajan S. 2001. Irrigation Equity: Impacts Sources and Strategies. Policy Brief paper 19 p. National Centre for Agricultural Economics and Policy Research, Pusa, New Delhi.

\section{How to cite this article:}

Mahesh P. Tripathi, R.K. Nema, M.K. Awasthi and Tiwari, Y.K. 2018. Performance Evaluation of a Minor Irrigation Project Using Canal Performance Indicator. Int.J.Curr.Microbiol.App.Sci. 7(01): 1895-1903. doi: https://doi.org/10.20546/ijcmas.2018.701.228 